\title{
Spawanie metodą CMT (Cold Metal Transfer) w porównaniu z klasyczną metodą MAG w przemyśle motoryzacyjnym
}

\author{
The welding process CMT (Cold Metal Transfer) compared \\ to the classical method of MAG in the automotive industry
}

\section{Streszczenie}

Obecnie jednym z wielu kierunków rozwoju zrobotyzowanych metod spawania jest łączenie cienkich blach z materiałów o jednakowych i różnorodnych właściwościach. Potrzeby przemysłu i łatwość zrobotyzowania metody MIG/MAG doprowadziły do szybkiego wdrożenia metody Cold Metal Transfer (CMT).

W artykule przedstawiono analizę metody CMT w odniesieniu do klasycznej metody MAG na przykładzie zrobotyzowanego spawania w przemyśle motoryzacyjnym. Do wykonania złączy próbnych zastosowano blachy ze stali S355MC o grubości $3 \mathrm{~mm}$, które stanowią elementy składowe spawanej konstrukcji oparcia fotela samochodowego. Wykonane połączenia próbne, przy zróżnicowanej energii liniowej spawania, poddano badaniom makrostrukturalnym oraz pomiarom twardości. Wyniki pomiarów obrazują wpływ energii liniowej spawania oraz prędkości podawania spoiwa na geometrię spoin i szerokość strefy wpływu ciepła [1].

Słowa kluczowe: spawanie zrobotyzowane, CMT, MAG, makrostruktura, geometria spoin, twardość, SWC

\begin{abstract}
Nowadays combining thin steel sheet with the same and different materials properties is one of the main routes robotized of welding. The needs of industry and ease of robotized MIG/MAG led to the rapid implementation Cold Metal Transfer method (CMT).

The article presented the analysis CMT method in comparison to classical method of MAG based on robotized welding in the automotive industry. Welded test joints are made of sheet steel S355MC thickness of $3 \mathrm{~mm}$, this material is used as a component for car seats. WeIding connections were investigated in macrostructure test and hardness with differentiated the Welding Energy Input. The measurement results reflect the impact of WeIding Energy Input and wire-feed speed on the geometry of the welds and heat affected zone width [1].
\end{abstract}

Keywords: robotic welding, CMT, MAG, macrostructure, geometry of welds, hardness, heat-affected zone

\section{Wstęp}

W standardowej metodzie MAG przenoszenie materiału dodatkowego w miejsce powstającej spoiny może mieć charakter kroplowo-zwarciowy, mieszany tzw. globularny i natryskowy. Rodzaj przenoszenia kropli w łuku elektrycznym zależy w dużym stopniu od gęstości prądu jarzącego się łuku. Krytyczna gęstość prądu przy spawaniu w osłonie gazów, drutem o średnicy 1,0 mm wynosi ok. $200 \mathrm{~A} / \mathrm{mm}^{2}$ [5]. Poniżej tej granicy występuje przenoszenie kroplowo-zwarciowe natomiast powyżej natryskowe. Zwiększenie wartości natężenia prądu zmniejsza rozmiar kropli.

Podczas procesu spawania MAG Standard do przepływu kropel dochodzi w następującej kolejności (rys. 1): 1 - dojście drutu do punktu startowego, 2 - start posuwu drutu i doprowadzenie do zajarzenia się łuku, 3 - poprzez energię cieplną jarzenia się łuku elektrycznego dochodzi do topienia się drutu i opadaniu kropel do jeziorka spawalniczego, 4 - przepływ kropel i topienie materiałów łączonych.

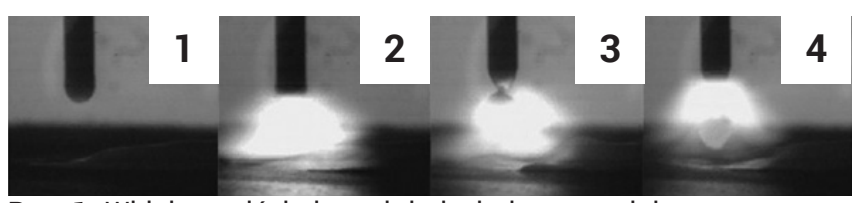

Rys. 1. Widok przejścia kropel do jeziorka spawalniczego w procesie MAG [6]

Fig. 1. View transition drops into the weld pool in the process of MAG [6]

Prof. dr hab. inż. Zbigniew Mirski, mgr inż. Piotr Pękala - Katedra Materiałoznawstwa, Wytrzymałości i Spawalnictwa, Wydział Mechaniczny Politechniki Wrocławskiej.

Autor korespondencyjny/Corresponding author: zbigniew.mirski@pwr.edu.pl 
Tablica I. Skład chemiczny stali S355MC [11]

Table I. The chemical composition of the steel S355MC [11]

\begin{tabular}{|c|c|c|c|c|c|c|c|c|c|}
\hline Oznaczenie & \multicolumn{10}{|c|}{ Skład chemiczny w \% wag. } \\
\hline \multirow{2}{*}{ S355MC } & $\mathrm{C}$ & $\mathrm{Si}$ & $\mathrm{Mn}$ & $\mathrm{P}$ & $\mathrm{S}$ & $\mathrm{Nb}$ & $\mathrm{V}$ & $\mathrm{Ti}$ & $\mathrm{Fe}$ \\
\cline { 2 - 22 } & 0,12 & 0,15 & 1,5 & 0,025 & 0,02 & 0,09 & 0,02 & 0,015 & reszta \\
\hline
\end{tabular}

Tablica II. Właściwości mechaniczne stali S355MC [11] Table II. Mechanical properties of steel S355MC [11]

\begin{tabular}{|c|c|c|c|}
\hline Oznaczenie & $\begin{array}{c}\text { Granica } \\
\text { plastyczności } \\
\text { Re min [MPa] }\end{array}$ & $\begin{array}{c}\text { Wytrzymałość } \\
\text { na rozciąganie } \\
\text { Rm [MPa] }\end{array}$ & $\begin{array}{c}\text { Wydłużenie } \\
\text { względne } \\
\text { A [\%] }\end{array}$ \\
\hline S355MC & 355 & $430-550$ & $19-23$ \\
\hline
\end{tabular}

Metoda CMT jest rozwinięciem metod MIG/MAG polegającym na ograniczeniu energii cieplnej wprowadzanej podczas spawania, jest jednym z niskoenergetycznych procesów spawania. Ciepło wprowadzane jest niższe niż podczas standardowego, zwarciowego procesu, osiągnięto to za pomocą kontrolowanego ruchu drutu elektrodowego, który cyklicznie rozpoczyna i wygasza łuk elektryczny. Impulsowe podawanie drutu podczas procesu CMT obrazuje rysunek 2. Cykl podawania kropli topionej elektrody jest następujący: 1 - start podawania drutu po dojeździe do punktu startowego, drut jest wysuwany od momentu zajarzenia się łuku elektrycznego do zwarcia z materiałem łączonym, podczas jarzenia się łuku dochodzi do topienia się elektrody i materiału łączonego oraz powstania kropli z zachowaniem posuwu drutu w kierunku spoiny, 2 - zwarcie drutu z materiałem, 3 - cofnięcie drutu i oderwanie od drutu kropli, która pozostaje w ciekłym jeziorku spawalniczym, 4 - przy ruchu powrotnym drutu dochodzi do ponownego zajarzenia łuku elektrycznego [8].

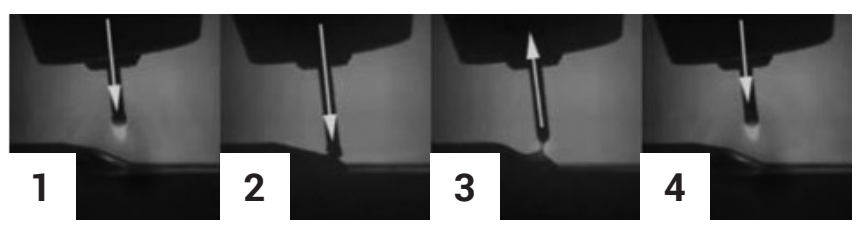

Rys. 2. Cykl ruchu drutu spawalniczego w procesie CMT [8]

Fig. 2. The movement cycle of welding wire in the process of CMT [8]

\section{Materiał zastosowany w badaniach}

Stal konstrukcyjna S355MC wg PN-EN 10149 jest stalą mikrostopową o podwyższonej granicy plastyczności, kształtowaną w procesie walcowania na gorąco. Skład chemiczny, właściwości mechaniczne podano odpowiednio

Tablica III. Zestawienie urządzeń wchodzących w skład stanowiska spawalniczego [6,15]

Table III. Devices belonging to welding station $[6,15]$

\begin{tabular}{|c|c|c|c|c|}
\hline $\mathrm{Nr}$ & Nazwa & Producent & Model & Opis \\
\hline 1 & $\begin{array}{l}\text { Szafa elektryczna } \\
\text { manipulatora }\end{array}$ & ABB & IRC5 & $\begin{array}{c}\text { zasilanie i sterowanie napędów } \\
\text { osi manipulatora i osi zewnętrznych }\end{array}$ \\
\hline 2 & $\begin{array}{l}\text { Panel sterowania } \\
\text { spawarki }\end{array}$ & Fronius & RCU 5000i & $\begin{array}{l}\text { nastawa i kontrola parametrów } \\
\text { procesu spawania }\end{array}$ \\
\hline 3 & Podajnik drutu & Fronius & VR 7000-CMT MO/K & $\begin{array}{l}\text { główny podajnik drutu, napęd sterowany } \\
\text { cyfrowo, układ czterech rolek dociskowych }\end{array}$ \\
\hline 4 & Chłodnica & Fronius & FK-4000-R-FC & $\begin{array}{c}\text { chłodnica płynowa, chłodząca przewód } \\
\text { prądowy i palnik spawalniczy }\end{array}$ \\
\hline 5 & $\begin{array}{l}\text { Źródło prądu } \\
\text { spawalniczego }\end{array}$ & Fronius & $\begin{array}{l}\text { TransPuls Synergic TPS } \\
4000 \mathrm{CMT}\end{array}$ & $\begin{array}{c}\text { inwerterowe źródło prądu, zasilane trójfazowo, } \\
\text { sterowane cyfrowo, zakres prądu 3-400 A, } \\
\text { napięcie robocze 14-34 V }\end{array}$ \\
\hline 6 & $\begin{array}{l}\text { Prowadzenie mediów } \\
\text { spawalniczych }\end{array}$ & Fronius & $6,25 \mathrm{~m}$ & $\begin{array}{l}\text { wiązka uchwytu robota, MIG/MAG CMT, } \\
\text { przewód prądowy chłodzony cieczą, przewody } \\
\text { chłodzące palnik, przewód gazu ochronnego, } \\
\text { prowadzenie drutu spawalniczego, przewody } \\
\text { sygnałowe }\end{array}$ \\
\hline 7 & Bufor drutu & Fronius & $\begin{array}{l}\text { zestaw } \\
\text { buforu } \\
\text { drutu CMT }\end{array}$ & $\begin{array}{l}\text { czujnik kontroli podawania drutu, } \\
\text { prowadzenie drutu, przewód sygnałowy }\end{array}$ \\
\hline 8 & Podajnik CMT & Fronius & Robacta Drive CMT & $\begin{array}{c}\text { silnik asynchroniczny prądu przemiennego, } \\
\text { bezprzekładniowe przeniesienie przeniesie- } \\
\text { nie napędu realizujące ruch drutu procesu } \\
\text { CMT }\end{array}$ \\
\hline 9 & Palnik spawalniczy & Fronius & R5000 & $\begin{array}{l}\text { palnik chłodzony cieczą, doprowadzający } \\
\text { gaz osłonowy i drut spawalniczy }\end{array}$ \\
\hline 10 & Manipulator & ABB & IRB 2400 & $\begin{array}{l}\text { sześcioosiowy manipulator } \\
\text { o udźwigu do } 200 \mathrm{~N}\end{array}$ \\
\hline 11 & $\begin{array}{l}\text { Pojemnik drutu } \\
\text { spawalniczego }\end{array}$ & ESAB & OK Autrod 12.51 & $\begin{array}{c}\emptyset 1,0 \mathrm{~mm}, \mathrm{G} 383 \mathrm{Cl} 3 \mathrm{Si1}, \\
\text { pojemnik } 250 \mathrm{~kg}\end{array}$ \\
\hline
\end{tabular}


Tablica IV. Instrukcja technologiczna spawania

Table IV. Welding procedure

\begin{tabular}{|c|c|c|c|c|c|c|c|}
\hline 岁然 & \multicolumn{5}{|c|}{ INSTRUKCJA TECHNOLOGICZNA SPAWANIA (WPS) } & \multicolumn{2}{|c|}{ Data aktualizacji: 25.03.2015 } \\
\hline \multicolumn{2}{|c|}{ WPS Nr: } & \multicolumn{2}{|c|}{$15 / 03 / 25 / 1$} & \multirow{2}{*}{\multicolumn{4}{|c|}{$\begin{array}{l}\text { Inspektor lub jednostka isnpekcyjna: } \\
\text { Wydział Mechaniczny }\end{array}$}} \\
\hline \multicolumn{2}{|c|}{ Wytwórca: } & \multicolumn{2}{|c|}{$\mathrm{PWr}$} & & & & \\
\hline \multicolumn{2}{|c|}{ Miejscowość: } & \multicolumn{2}{|c|}{ Wrocław } & \multirow{2}{*}{\multicolumn{4}{|c|}{$\begin{array}{l}\text { Sposób przygotowania złącza: } \\
\text { I - bez ukosowania }\end{array}$}} \\
\hline \multicolumn{2}{|c|}{ Proces spawania: } & \multicolumn{2}{|c|}{135} & & & & \\
\hline \multicolumn{2}{|c|}{ Źródłó prądowe: } & \multicolumn{2}{|c|}{$\begin{array}{l}\text { TransPuls Synergic } \\
\text { TPS } 4000 \mathrm{CMT}\end{array}$} & \multicolumn{4}{|c|}{$\begin{array}{l}\text { Specyfikacja materiału podstawowego: } \\
\text { S355MC, blacha } 90 \times 45 \times 3 \mathrm{~mm}\end{array}$} \\
\hline \multicolumn{2}{|c|}{ Manipulator: } & \multicolumn{2}{|c|}{ ABB IRB 2400} & \multicolumn{2}{|c|}{ Grubość materiału: } & \multicolumn{2}{|c|}{$3 \mathrm{~mm}$} \\
\hline \multicolumn{2}{|c|}{$\begin{array}{l}\text { Postać materiału } \\
\text { i rodzaj spoiny: }\end{array}$} & \multicolumn{2}{|c|}{ P/BW -blacha/czołowa } & \multicolumn{2}{|c|}{ Pozycja spawania: } & \multicolumn{2}{|c|}{ PA - podolna } \\
\hline \multicolumn{8}{|c|}{ Szczegóły przygotowania do spawania (schemat) } \\
\hline \multicolumn{4}{|c|}{ Przygotowanie złącza: } & \multicolumn{4}{|c|}{ Pozycja i kierunek spawania, nachylenie palnika } \\
\hline \multicolumn{4}{|c|}{0,5} & \multicolumn{4}{|c|}{ 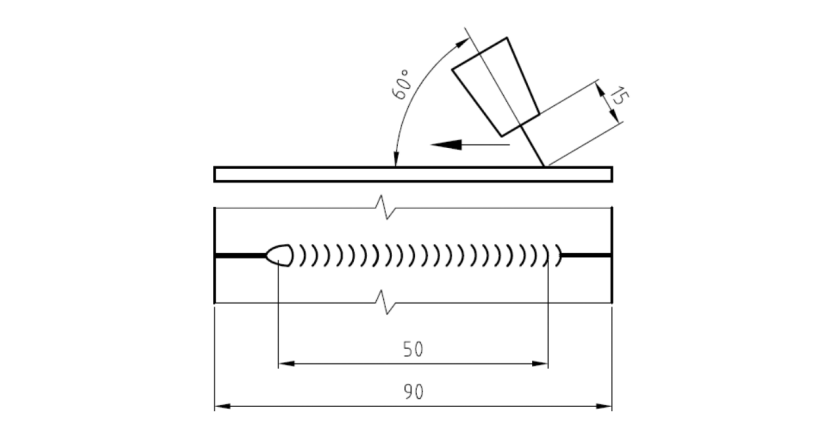 } \\
\hline Nr próbki & Proces & $\begin{array}{l}\text { Natężenie } \\
\text { prądu } \\
\text { [A] }\end{array}$ & $\begin{array}{l}\text { Napięcie łuku } \\
\text { [V] }\end{array}$ & $\begin{array}{l}\text { Prędkość } \\
\text { podawania } \\
\text { drutu } \\
\text { [m/min] }\end{array}$ & $\begin{array}{l}\text { Prędkość } \\
\text { spawania } \\
\text { [m/min] }\end{array}$ & $\begin{array}{l}\text { Średnica } \\
\text { spoiwa } \\
\text { [mm] }\end{array}$ & $\begin{array}{l}\text { Energia } \\
\text { liniowa sp. } \\
{[\mathrm{kJ} / \mathrm{cm}]}\end{array}$ \\
\hline 1 & Standard & 184 & 21,1 & 9 & 0,7 & $\varnothing 1,0$ & 2,00 \\
\hline 2 & Standard & 191 & 22 & 9,5 & 0,7 & $\varnothing 1,0$ & 2,16 \\
\hline 3 & Standard & 198 & 23 & 10 & 0,7 & $\varnothing 1,0$ & 2,34 \\
\hline 4 & Standard & 204 & 23,9 & 10,5 & 0,7 & $\varnothing 1,0$ & 2,51 \\
\hline 5 & Standard & 236 & 26,7 & 11 & 0,7 & $\emptyset 1,0$ & 3,24 \\
\hline 1 & CMT & 185 & 14,5 & 9 & 0,7 & $\emptyset 1,0$ & 1,38 \\
\hline 2 & СMT & 191 & 15,1 & 10 & 0,7 & $\emptyset 1,0$ & 1,48 \\
\hline 3 & СMT & 197 & 15,7 & 11 & 0,7 & $\emptyset 1,0$ & 1,59 \\
\hline 4 & СMT & 218 & 16,5 & 12 & 0,7 & $\emptyset 1,0$ & 1,85 \\
\hline 5 & СMT & 230 & 17 & 13 & 0,7 & $\emptyset 1,0$ & 2,01 \\
\hline \multirow{2}{*}{\multicolumn{4}{|c|}{$\begin{array}{l}\text { Klasyfikacja spoiwa i nazwa handlowa: } \\
\text { G383C13Si1 Ø1 mm, OK Autrod 12.51 ESAB }\end{array}$}} & \multicolumn{4}{|c|}{ Dodatkowe informacje: } \\
\hline & & & & Rodz & ciegu: & & \\
\hline Gaz & by: & M21 & $5 \% \mathrm{CO}_{2}$ & Korekcja & gości łuku: & & \\
\hline Prze & lazu: & & $\min$ & Korekcj & ynamiki: & & \\
\hline & & & & Kąt ustan & ia palnika: & & \\
\hline $\begin{array}{l}\text { Temp. } \\
\text { ws }\end{array}$ & $\begin{array}{l}\text { ewania } \\
\text { go: }\end{array}$ & tempera & otoczenia & $\begin{array}{l}\text { Odległ } \\
\text { od } m\end{array}$ & $\begin{array}{l}\text { palnika } \\
\text { riału: }\end{array}$ & & \\
\hline Prędkos & dzenia: & & ietrzu & Obróbka ciep & po spawaniu: & & \\
\hline
\end{tabular}


w tablicach I i II. Dla stali S355MC równoważnik węgla wynosi $\mathrm{CEV}=0,374 \%$, przy maksymalnej zawartości składu chemicznego, stanowi to zachowanie warunku dobrej spawalności metalurgicznej materiału.

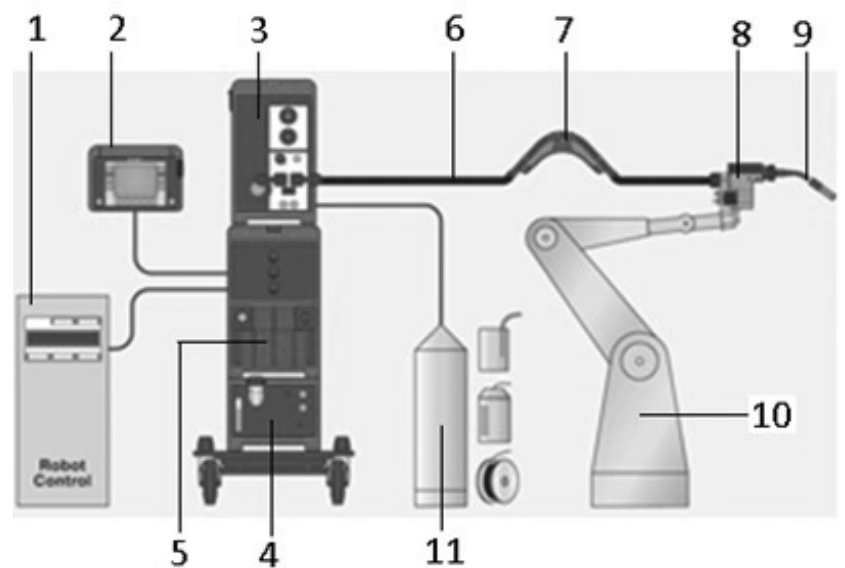

Rys. 3. Schemat podłączenia urządzeń na stanowisku: 1 - szafa elektryczna manipulatora, 2 - panel sterowania spawarki, 3 - podajnik drutu, 4 - chłodnica, 5 - źródło prądu spawalniczego, 6 - prowadzenie mediów spawalniczych, 7 - bufor drutu, 8 - podajnik CMT, 9 - palnik spawalniczy, 10 - manipulator, 11 - pojemnik drutu spawalniczego [6] Fig. 3. Connections diagram: 1 - robot controller, 2 - control panel, 3 - wire feed unit, 4 - cooling unit, 5 - power source, 6 - package of welding media, 7 - wire buffer, 8 - feeder CMT, 9 - welding torch 10 - manipulator, 11 - container of welding wire [6]

\section{Stanowisko spawalnicze}

Schemat urządzeń wchodzących w skład zrobotyzowanego stanowiska spawalniczego pokazano na rysunku 3. Krótką charakterystykę elementów składowych stanowiska zamieszczono w tablicy III.

\section{Dobór warunków i parametrów spawania}

Ze względu na grubość blach równą $3 \mathrm{~mm}$, przygotowano je bez ukosowania krawędzi. Założono wykonanie spoin czołowych, jednostronnych z pojedynczym prostym ściegiem. Ze względu na grubość blach, brak ukosowania, rodzaj spoiny I oraz średnicę drutu elektrodowego (Ø 1,0 mm), dobrano odstęp między blachami równy $0,5 \mathrm{~mm}$.

Przy wykonywaniu połączeń próbnych metodami MAG Standard i CMT zachowano podobne warunki spawania. Dobór natężenia prądu spawania dla obu metod mieścił się w zakresie 180 - 240 A. Charakterystyka napięciowa była automatycznie dobierana do zadanej wartości natężenia prądu, prędkości podawania drutu oraz stosowanej metody (Standard lub CMT). Wykonano po 5 złączy próbnych, z rosnącymi wartościami prędkości podawania drutu. Wszystkie pozostałe parametry, warunki spawania oraz użyte materiały i urządzenia zawarto w Instrukcji Technologicznej Spawania WPS (tablica IV).

\section{Badania makrostruktury połączeń spawanych}

Badania metalograficzne połączeń spawanych wykonano na przekrojach poprzecznych, pobranych w połowie długości złączy. Próbki szlifowano na wodnych papierach ściernych SiC oraz polerowano stosując wodną zawiesinę tlenku glinu. Próbki do badań makroskopowych trawiono w $30 \%$ roztworze chlorku żelaza III $\left(\mathrm{FeCl}_{3}\right)$. Do obserwacji i pomiarów spoin użyto mikroskopu świetlnego firmy Struers oraz oprogramowania Welding Exper wersja 2.70, przy powiększeniu 45x. Zestawienie wyników pomiarów zamieszczono w tablicach V i VI. Oznaczenia wymiarów spoin pokazano na rysunku 4 . W oznaczeniu spoiny podano proces i prędkość podawania spoiwa $\mathrm{w} \mathrm{m} / \mathrm{min}$ (np. $\mathrm{S} 9$ - Standard $9 \mathrm{~m} / \mathrm{min}$ ). Przykładowe makrostruktury spoin pokazano na rysunkach 5 i 6 .

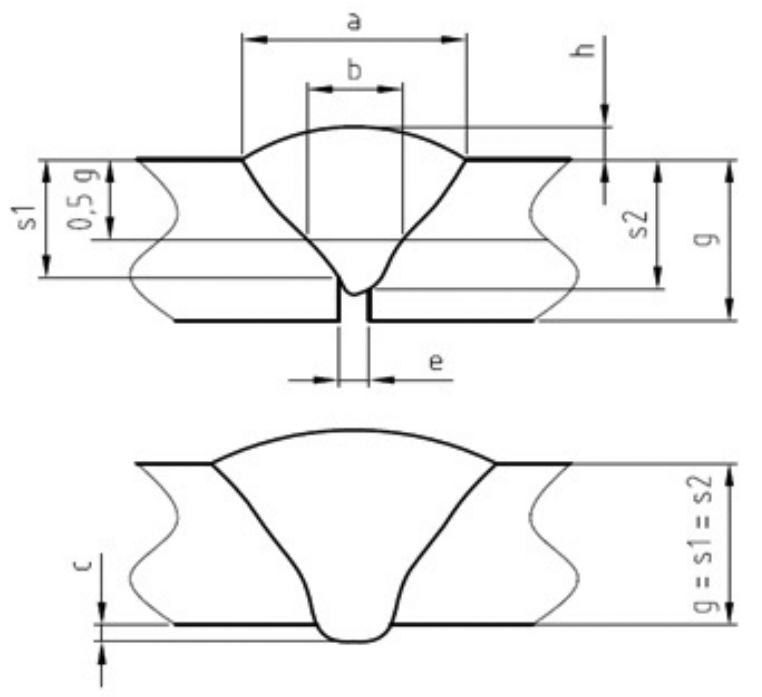

Rys. 4. Oznaczenia wymiarów spoin

Fig. 4. Dimensions of the welds

Tablica V. Zestawienie wymiarów spoin wykonanych metodą CMT Standard

Table V. The dimensions of the welds made CMT Standard

\begin{tabular}{|c|c|c|c|c|c|c|c|c|c|}
\hline \multicolumn{10}{|c|}{ Wymiary spoin [mm] } \\
\hline Lp & $\begin{array}{c}\text { Oznaczenie } \\
\text { spoiny }\end{array}$ & $\begin{array}{c}\text { wtopienie } \\
\text { s1 }\end{array}$ & $\begin{array}{c}\text { szerokość } \\
\text { lica } \\
\text { a }\end{array}$ & $\begin{array}{l}\text { wtopienie } \\
\text { s2 }\end{array}$ & $\begin{array}{c}\text { szerokość } \\
\text { spoiny } \\
\text { w połowie } \\
\text { grubości } \\
\text { blach } \\
\text { b }\end{array}$ & $\begin{array}{l}\text { odstęp } \\
\text { od strony } \\
\text { grani } \\
\text { e }\end{array}$ & $\begin{array}{c}\text { wyciek } \\
\text { grani } \\
\text { c }\end{array}$ & $\begin{array}{c}\text { wysokość } \\
\text { spoiny } \\
\text { h }\end{array}$ & $\begin{array}{c}\text { Średnie } \\
\text { wtopienie } \\
(s 1+s 2) / 2\end{array}$ \\
\hline 1 & s9 & 2,60 & 6,10 & 2,79 & 1,41 & - & - & 1,86 & 2,70 \\
\hline 2 & s9,5 & 2,21 & 6,52 & 2,29 & 1,33 & 0,43 & - & 2,08 & 2,25 \\
\hline 3 & S10 & 3,04 & 6,86 & 3,00 & 1,56 & - & 0,22 & 1,99 & 3,02 \\
\hline 4 & $S 10,5$ & 2,98 & 7,75 & 3,00 & 2,69 & - & 0,66 & 1,66 & 2,99 \\
\hline 5 & S11 & 3,02 & 9,16 & 3,00 & 2,59 & - & 0,60 & 1,50 & 3,01 \\
\hline
\end{tabular}




\section{Pomiary twardości}

Pomiary twardości połączeń spawanych wykonano metodą Vickersa przy obciążeniu 10 kG (HV 10). Pomiarów dokonano wg normy PN-EN ISO 6507-1:2007 Metale - Pomiar twardości metodą Vickersa, część 1: Metody badań. Użyto twardościomierza firmy Fritz Heckert. Schemat przeprowadzenia pomiarów przedstawiono na rysunku 9. Pomiarów dokonano z odstępem $1 \mathrm{~mm}$, symetrycznie po obu stronach osi spoiny. Rysunki 10 i 11 obrazują rozkłady twardości w złączach spawanych. Pomiary o numerach: -1, 0, 1 wykonano w obszarze spoiny, na rysunkach 10 i 11 zaznaczono wartość średnią tych pomiarów. Średnia twardość materiału rodzimego wynosiła 155 HV 10.

Szerokość strefy wpływu ciepła wyznaczono na podstawie rozkładów twardości, uwzględniając odległość punktów

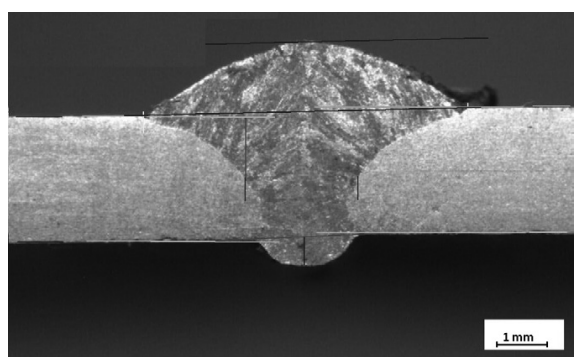

Rys. 5. Makrostruktura złącza nr 4, metoda MAG Standard, natężenie prądu $204 \mathrm{~A}$, napięcie łuku $23,9 \mathrm{~V}$, prędkość podawania drutu $10,5 \mathrm{~m} / \mathrm{min}$, prędkość spawania $0,7 \mathrm{~m} / \mathrm{min}$

Fig. 5. Macrostructure connection No 4, MAG standard, current 204 A, the arc voltage $23.9 \mathrm{~V}$, the wire feed speed of $10.5 \mathrm{~m} / \mathrm{min}$, the welding speed of $0.7 \mathrm{~m} / \mathrm{min}$

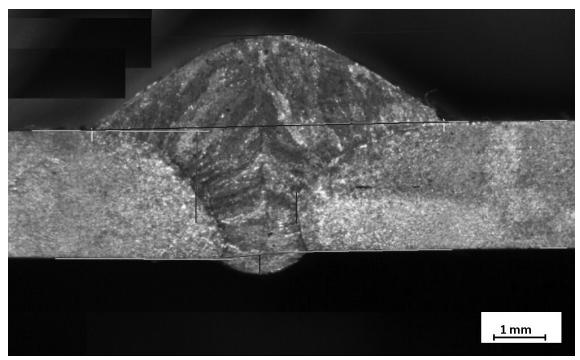

Rys. 6. Makrostruktura złącza nr 5, metoda MAG CMT, natężenie prądu $230 \mathrm{~A}$, napięcie łuku $17 \mathrm{~V}$, prędkość podawania drutu $13 \mathrm{~m} / \mathrm{min}$, prędkość spawania $0,7 \mathrm{~m} / \mathrm{min}$

Fig. 6. Macrostructure connection No 5, MAG CMT, current $230 \mathrm{~A}$ the arc voltage $17 \mathrm{~V}$, the wire feed speed of $13 \mathrm{~m} / \mathrm{min}$, the welding speed of $0.7 \mathrm{~m} / \mathrm{min}$ pomiarowych. Rozkład twardości HV 10 w złączach próbnych był symetryczny po obu stronach spoiny. Szerokość strefy wpływu ciepła w zależności od energii liniowej spawania oraz prędkości podawania spoiwa pokazano na rysunkach 12 i 13. Szerokość SWC w próbnych złączach wykonanych metodą MAG Standard wynosiła ok. $4-5,2$ $\mathrm{mm}$, a w metodzie MAG CMT zmniejszyła się do wartości ok. 2,2-3,6 mm.

Podczas wykonywania złączy metodą CMT rozprysk kropel był minimalny. Brak rozprysków był zauważalny podczas jarzenia się łuku elektrycznego oraz podczas kontroli stanu osprzętu spawalniczego. Przy stosowaniu procesu CMT zaobserwowano dłuższy czas pracy dysz gazowych, mniejsze zużycie układów elektrycznych i pneumatycznych, krótszy czas rutynowego sprzątania cel spawalniczych i układów pozycjonujących detale.

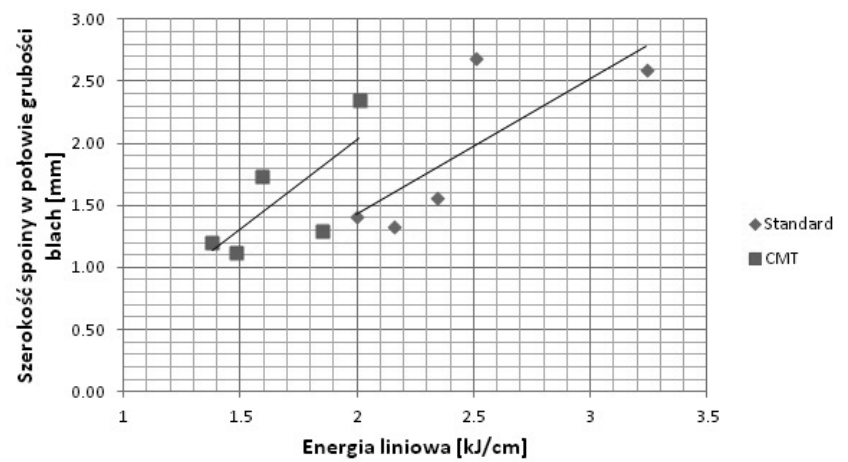

Rys. 7. Wpływ energii liniowej spawania na szerokość spoiny w połowie grubości blach ze stali S355MC

Fig. 7. Impact heat input on the weld width at half the thickness of steel sheets S355MC

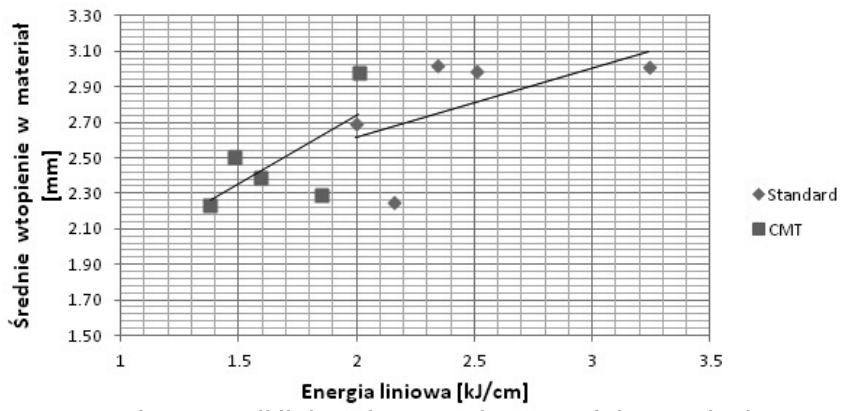

Rys. 8. Wpływ energii liniowej spawania na średnie wtopienie w materiał rodzimy S355MC

Fig. 8. Impact heat input on average penetration in the native material S355MC

Tablica VI. Zestawienie wymiarów spoin wykonanych metodą MAG CMT Table VI. The dimensions of the welds made MAG CMT

\begin{tabular}{|c|c|c|c|c|c|c|c|c|c|}
\hline \multicolumn{10}{|c|}{ Wymiary spoin [mm] } \\
\hline Lp & $\begin{array}{c}\text { Oznaczenie } \\
\text { spoiny }\end{array}$ & $\begin{array}{c}\text { wtopienie } \\
\text { s1 }\end{array}$ & $\begin{array}{c}\text { szerokość } \\
\text { lica } \\
\text { a }\end{array}$ & $\begin{array}{c}\text { wtopienie } \\
\text { s2 }\end{array}$ & $\begin{array}{c}\text { szerokość } \\
\text { spoiny } \\
\text { w połowie } \\
\text { grubości } \\
\text { blach } \\
\text { b }\end{array}$ & $\begin{array}{l}\text { odstęp } \\
\text { od strony } \\
\text { grani } \\
\text { e }\end{array}$ & $\begin{array}{c}\text { wyciek } \\
\text { grani } \\
\text { c }\end{array}$ & $\begin{array}{c}\text { wysokość } \\
\text { spoiny } \\
\text { h }\end{array}$ & $\begin{array}{c}\text { Średnie } \\
\text { wtopienie } \\
(\mathrm{s} 1+\mathrm{s} 2) / 2\end{array}$ \\
\hline 1 & CMT 9 & 2,17 & 6,76 & 2,30 & 1,20 & 0,63 & - & 1,55 & 2,24 \\
\hline 2 & CMT 10 & 2,31 & 6,03 & 2,69 & 1,12 & 0,66 & - & 1,77 & 2,50 \\
\hline 3 & CMT 11 & 2,42 & 7,37 & 2,35 & 1,74 & 0,67 & - & 2,02 & 2,39 \\
\hline 4 & CMT 12 & 2,12 & 7,46 & 2,46 & 1,29 & 0,44 & - & 2,28 & 2,29 \\
\hline 5 & СMT 13 & 2,98 & 8,23 & 2,98 & 2,35 & - & 0,41 & 2,12 & 2,98 \\
\hline
\end{tabular}




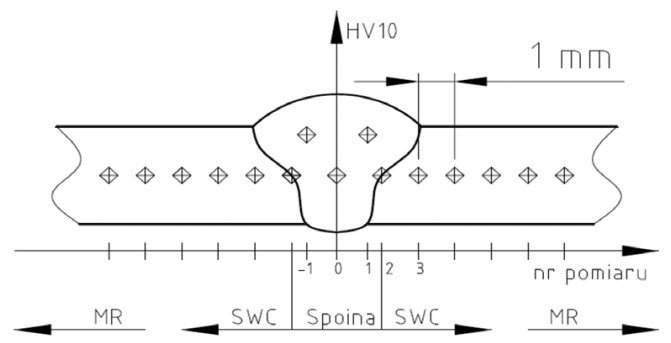

Rys. 9. Schemat pomiarów twardości HV 10

Fig. 9. Diagram of hardness measurements HV 10

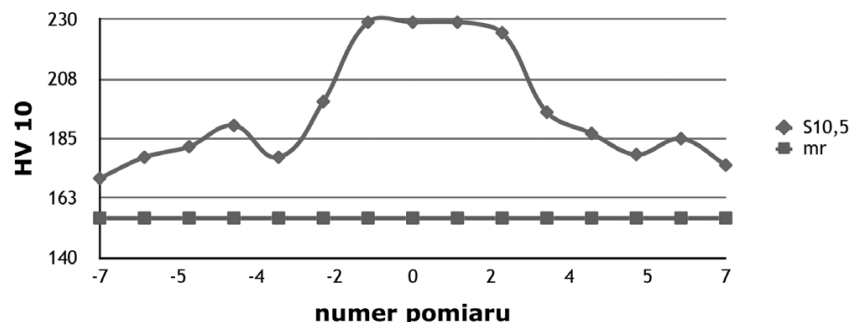

Rys. 10. Rozkład twardości HV 10 w złączu nr 4, metoda MAG Standard Fig. 10. The function of hardness in the connector No 4, MAG Standard

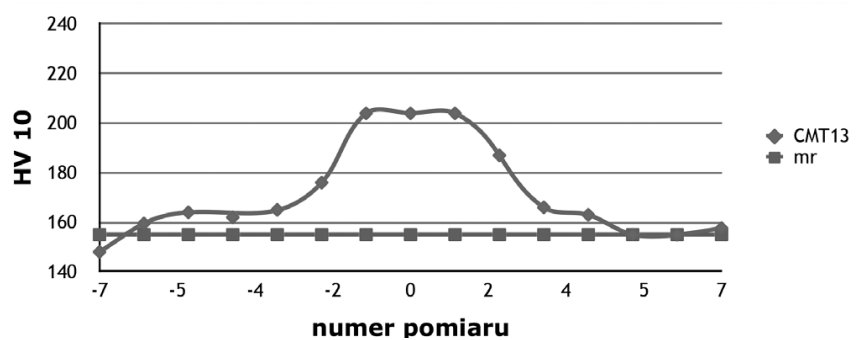

Rys. 11. Rozkład twardości HV 10 w złączu nr 5, metoda MAG CMT Fig. 11. The function of hardness in the connector No 5, MAG CMT

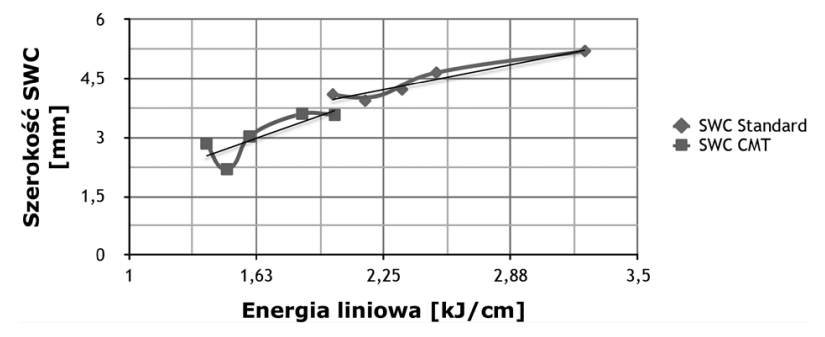

Rys. 12. Wpływ energii liniowej spawania na szerokość SWC

Fig. 12. Impact heat input on the width of the heat-affected zone

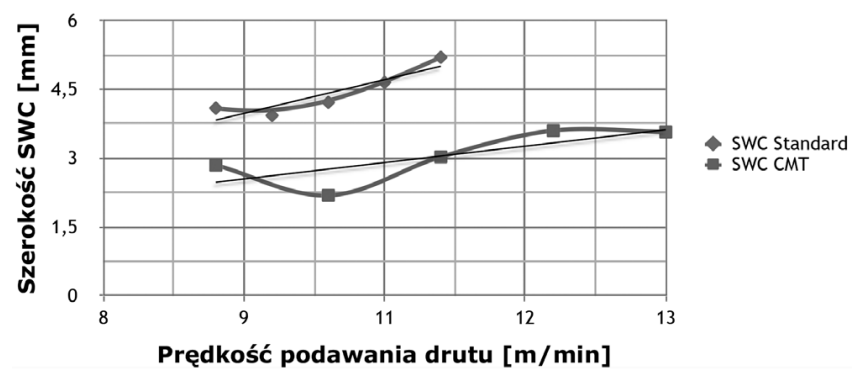

Rys. 13. Wpływ prędkości podawania drutu na szerokość SWC

Fig. 13. Impact wire feed speed on the width of the heat-affected zone

\section{Wnioski}

Na podstawie przeprowadzonych badań sformułowano następujące wnioski:

- Porównanie zrobotyzowanego spawania metodą MAG Standard i MAG CMT wykazało, że sposób dozowania spoiwa i przechodzenia kropli w łuku elektrycznym ma znaczący wpływ na powstałą geometrię spoiny i szerokość strefy wpływu ciepła w złączach doczołowych, o grubości $3 \mathrm{~mm}$, ze stali S355MC.

- Osiągnięcie tej samej szerokości spoiny w połowie grubości spawanego materiału jest możliwe przy mniejszej energii liniowej za pomocą metody CMT. Osiągnięcie tej samej szerokości lica spoiny jest możliwe przy mniejszej energii liniowej za pomocą metody CMT, w zakresie pracy, do maksymalnej, stosowanej wartości natężenia prądu spawania metodą CMT.

- Metoda MAG Standard umożliwia osiągnięcie większego wtopienia w materiał rodzimy. Przy tych samych prędkościach podawania drutu osiąga się większe wtopienie w materiał rodzimy aniżeli w przypadku metody MAG CMT.

- Pomiary twardości metodą Vickersa HV 10 obrazują mniejszy wpływ procesu CMT w porównaniu z procesem MAG Standard na szerokość strefy wpływu ciepła. Ogólnie można stwierdzić, że SWC w metodzie MAG CMT jest węższa o 1,5 - 2 mm, w zależności od parametrów spawania.

\section{Literatura}

[1] Pękala P.: Analiza technologii spawania w procesie CMT (Cold Metal Transfer) w porównaniu z klasyczną metodą MAG, Praca magisterska pod kier. prof. Z. Mirskiego, Wydział Mechaniczny Politechniki Wrocławskiej, Wrocław 2015.

[2] Pilarczyk J. (red.): Poradnik Inżyniera - Spawalnictwo tom 2, WNT, Warszawa 2005.

[3] Dąbrowski A.: Urządzenia spawalnicze - Budowa i charakterystyki, Przegląd Spawalnictwa, $\mathrm{nr} 7 / 2010$, s. 24-32.

[4] www.tecweld.pl, dostęp w dniu 25.04.2015.

[5] Pilarczyk J. (red.): Poradnik Inżyniera - Spawalnictwo tom 1, WNT, Warszawa 2003.

[6] www.fronius.com, dostęp w dniu 26.04.2015

[7] Wilden J., Bergmann J. P., Reich S., Goecke S.: Beztopnikowe niskotemperaturowe spajanie lekkich konstrukcji różnoimiennych metodą sterowanego łuku zwarciowego, Przegląd Spawalnictwa, nr 9/2007, s. 77-81.

[8] Grzybicki M., Jakubowski J.: Badania porównawcze spawania blach ze stali karose ryjnej metodami CMT oraz MIG/MAG, Przegląd Spawalnictwa, nr 10/2009, s. 32-36.
[9] Bruckner J.: Metoda CMT - rewolucja w technologii spawania, Przegląd Spawalnictwa, nr 7-8/2009, s. 24-28.

[10] Kudła K., Wojsyk K.: Normowana energia liniowa a ilość ciepła wprowadzanego podczas spawania, Przegląd Spawalnictwa, nr 12/2010, s. 21-25.

[11] www.universal-stal.pl, dostęp w dniu 26.04.2015

[12] Dobrzański L. A. : Podstawy nauki o materiałach i metaloznawstwo, WNT, Warszawa 2002.

[13] www.harispal.pl, dostęp w dniu 09.05.2015, Madej Ł. (prezentacja): Korzystna struktura krystaliczna w strefie wpływu ciepła.

[14] www.automatykaonline.pl, dostęp w dniu 16.05.2015.

[15] www.ABB.com, dostęp w dniu 16.05.2015. 